\title{
He who pays the piper calls the tune? Setting the stage for an informed discourse on third-party funding of academic business research
}

\author{
Matthias Fink ${ }^{1,2}$ (D) Isabella Hatak ${ }^{3,4} \cdot$ Markus Scholz $^{5} \cdot$ Simon Down $^{2}$
}

Received: 26 May 2019 / Accepted: 21 October 2019 / Published online: 5 November 2019

(c) The Author(s) 2019

\begin{abstract}
Third-party funding of academic research has grown rapidly in its scope and impact. However, several forces demand greater attention to potential opportunities, challenges and threats of third-party research funding. Adopting a historical approach rooted in Anglo-Saxon academia, we discuss what third-party research funding means for European business researchers, which opportunities and tensions arise, and how to best manage them in the interest of the diverse stakeholders of our field. Finally, we introduce the six papers in this special issue and how they move the conversation on third-party research funding forward. The evidence base provided here is composed of a rich blend of empirical data, reflections on personal experience and conclusions drawn from formal mathematical models. As a result, the collection of papers offers a kaleidoscope of the state-of-the-art of research on third-party funding of academic business research in Europe. The insights emerging from these six papers collapse into a clear overall picture with each paper contributing a distinct jigsaw piece, a picture we present and discuss in this paper.
\end{abstract}

Keywords Academic research · Third-party funding · Europe - Empirical evidence · Conceptual framework

Mathematics Subject Classification 91C · 90B

Financing academic business research is increasingly shifting from public university budgets towards third party funds (EUA - European University Association 2015). This trend originates in the Anglo-Saxon academy and is currently spreading to scientific communities around the globe. This change not only disrupts research in natural sciences and engineering but also in all other disciplines such as the humanities and social sciences. In addition to the long-standing cooperation between national

Matthias Fink

matthias.fink@jku.at

Extended author information available on the last page of the article 
and supranational competitive public research funds, universities and business schools increasingly rely also on financing from private individuals, companies or private foundations. Such third-party funds are typically earmarked assets devoted to increase infrastructure (i.e., buildings, lecture halls, IT systems etc.) but also scholarships programmes, endowed chairs and whole research centres. While, in the Anglo-Saxon academy, these practices have been the norm from the outset of the university system, in mainland European universities and business schools they used to be less common and the idea and practice of third-party funding is still emerging (Lenzen 2015).

This difference is not only rooted in different academic traditions and diverging roles of governmental institutions in funding landscapes, but also due to a lack of systematic knowledge on how to establish and manage third-party funded research in mainland European academic institutions (Scherer et al. 2005). Looking back in history, in continental Europe, independence from the ruling class was perceived as a major achievement of civic society that fostered both independence in research as well as broad access to education and, thus, enhanced social mobility (Baumgart 2006). This process was part of the transformation of most continental European countries moving from monarchies towards representative democracies. While private universities maintained an important role in the education market, this development resulted in the strong belief that government represents the taxpayers and thus is responsible for financing an independent university system that provides education and research for the benefits of all (Zwick 2010). The idea and practice of thirdparty funding that increasingly spills over from the Anglo-Saxon countries, thus, does not properly fit the mainland European logic of governing the tertiary education sector. However, this clash of institutional logics cannot serve as an excuse to block innovation in the university sector-even more as policy and practice alike increasingly level criticism against business schools boiling down to academia generating knowledge that is less and less relevant to society paying the bill. Thus, pointing at traditions cannot be a reason to hinder further development. Rather the decision of mainland European universities whether to follow the trend of third-party funding needs to be taken consciously based on a proper evidence base (Geuna and Martin 2003).

However, this evidence base is quite weak so far. The potential opportunities, challenges and threats of third-party funding of mainland European universities are not well understood. This is especially true for research into the role and impact of third-party funding of academic activities outside the Anglo-Saxon academy. Thus, now it is time to reflect and evaluate which aspects of third-party funded research should or should not be established in mainland European universities and business schools and, where it has been adopted and to what extent, how it changes the multilevel academic landscape.

With this special issue we address this research gap by taking an evidence-based look at various aspects of third-party funding of academic research by private individuals and companies in continental Europe. The evidence base is composed of a rich blend of empirical data, reflections on personal experience and conclusions drawn from formal mathematical models. Current practices in the Anglo-Saxon academy serve as a background for fruitful inter-contextual comparison. 
Our interest is especially directed towards industry-based and private funding of academic activities in business and management studies. Management departments at universities and business schools are the centre of attention for this special issue because in the public austerity discourse, this discipline is especially under pressure to attract third-party funding from private individuals and companies, since findings are assumed to be directly exploitable by the funders. For example, it is often argued that research on management practices should, at least partially, be financed by business owners, because it is they who learn and profit from the research findings (Starkey and Madan 2001).

In order to set the stage for a more informed discourse, in a rigorous editorial process, we selected six papers by scholars from diverse countries within mainland Europe and the UK. The papers in this special issue help to increase the knowledge on third-party funding of academic research. Each of the papers takes a distinct perspective on third-party funding of academic research in the field of business and management studies especially at European universities and business schools. With their distinct approaches to this general topic, the authors also draw their conclusions on the basis of different units of analysis, and conceptual as well as methodological approaches. As a result, the collection of papers presented in this special issue offers a kaleidoscope of the state-of-the-art of research on third-party funding of academic business research in Europe. The insights emerging from these six papers, however, collapse into a clear overall picture with each paper contributing a distinct jigsaw piece, a picture we now present.

Key Insight 1: While the share of third-party funds in the overall university budget in Austria has constantly been growing over the last decade, the relevance greatly differs between universities and strongly fluctuates from year to year.

The contribution titled "The Shift towards Entrepreneurial Universities and the Relevance of Third-Party Funding of Business \& Economics Units in Austria - A Research Note" by Melanie Wiener, Daniela Maresch and Robert Breitenecker describes the changing role of third-party funding in the financial structure of the seven public universities in Austria over the last decade. Data retrieved from different sources is creatively combined to illustrate the shift towards entrepreneurial universities. Besides general comparisons between third party funding and other sources of finance the authors zoom in on the structure of the thirdparty funds and explore their different sources. In particular, they provide empirical evidence for the relevance of third-party funding of academic units devoted to business studies. Interestingly, the analysis shows that not all universities follow the general trend of a growing share of third-party funding in their overall budgets and that this share is highly volatile for most Austrian public universities.

Key Insight 2: A continuous flow and sustainable commitment to third-party funding reinforce universities' reputation.

In their paper "A Mathematical Model for the Role of Third-Party Funding in Reputation Building of Academic Institutions" Juan Pineiro-Chousa and Marcos 
Vizcaíno-González present a mathematical formalization for the reputational dimension of third-party funding in academic institutions. They develop a stochastic partial differential equation, and use its solution to deploy a sensitivity analysis to identify how the value of reputation reacts to changes in key variables. Among other factors they find that the sustainable commitment to third party funding enhances universities' reputation. However, high volatility of third-party funds is hampering universities' reputation.

Key insight 3: Overreliance on third-party funding threatens business schools' credibility, which is central to their attractiveness to students, scholars and decision makers.

Drawing on contemporary and historical discourse on UK business schools and insights from the sociology of scientific knowledge, Chris Ivory and Helen Shipton in their paper titled "Woolgar and Latour's 'Cycle of Scientific Credibility' as a Basis for Conceptualizing Business School Strategy" argue that business schools should not be understood and judged as engines of knowledge production, but rather as producers of credibility. They stress "credibility" as the key factor underlying the attractiveness of business schools to students and other key stakeholders. Thus, they call for credibility, and the mechanisms through which credibility are maintained, to be at the centre of strategic thinking within business schools. The authors warn that over-reliance on funding from corporate sources (in particular) might have profound consequences for the ability of schools to continue maintain credibility in the market for students and staff. The arguments developed in this article are based on rich data covering the development of business schools across the UK.

Key insight 4: In receiving third-party funds, researchers are prepared to compromise their operational autonomy but not their scientific autonomy.

Kasia Zalewska-Kurek and Rainer Harms present their findings on the effect of third-party funding on the autonomy of $\mathrm{PhD}$ researchers in their contribution titled "Managing Autonomy in University-industry Research: A Case of Collaborative PhD Projects in the Netherlands". Their starting point is the observation that increasing numbers of $\mathrm{PhD}$ projects are funded by industry partners. They argue that having an industry partners on board might potentially compromise researcher autonomy. The qualitative analysis of data collected from 14 management scholars who work in collaborative PhD projects with industry partners reinforces the idea of third-party funds threatening researchers' autonomy. The analysis also highlights a duality of strategically planned and opportunity-driven behavior in managing autonomy in third-party funded research. Researchers seem to make a strategic choice when trading in operational autonomy for funding. However, when it comes to research decisions, i.e. epistemological orientation or methodological choices, researchers' preferences for autonomy are strong and third-parties' attempts to interfere are usually declined. The authors also identify the researchers' orientations towards practice or theory and the governance mechanisms to affect researchers' choices in industry-research partnerships. 
Key insight 5: Framing the tensions arising from a diverse funding base of business research as a paradox helps universities to successfully and sustainably manage third-party funds.

In their article "Multiple-party funding: Tensions and related Consequences for Academic Research in Europe" Karin Link and Barbara Müller adopt a paradox perspective to identify the tensions that result from multiple-party funding and explore the consequences of the different funding strategies for business research. Their paper builds on an in-depth case study and offers practical advice for how academic institutions can successfully and sustainably manage multipleparty funded business research. Interestingly, this paper expands the focus of the discussion to academic research units that are external to universities. Even if the authors acknowledge substantial differences between university and non-university business research units, they argue that both face similar challenges to manage the tensions arising from different logics inherent in research funding from different sources. They conclude that an active and strategic management of these tensions is key to a successful and sustainable multi-source funding of business research.

Key insight 6: Third party funding of academic units implies threats for the freedom of research and teaching that can, however, be mitigated when appropriately addressed by university management.

The final paper in our special issue is authored by Christoph Badelt who guided the successful repositioning of the WU Vienna University of Business and Economics, a major European academic institution with over 1000 employees and around 21,000 business students, in the international market of academic education. In his article titled "Private External Funding of Universities: Blind Alley or New Opening?" the author reflects on the role of third-party funding in the transition of this institution towards a EQUIS, AACSB, AMBA accredited player in the highly competitive international market of tertiary education. He openly shares his experiences collected during the 13 years of serving as rector. His reflections-illustrated by numerous examples-highlight the relevance of distinguishing between different types of third-party funding and of a clear understanding of their specific implications for the independence of research and teaching as well for the sustainable development of a university. He emphasises that a fair balance needs to be established in the recognition of public and private contributions to the university budget.

Taken as a whole the papers in this special issue stimulate a number of new conversations and debates regarding the role of third-party funding in business research. Reflecting the paucity of research and baseline knowledge, a special issue on the topic can only provide incisive and particular insights, throwing up new questions. Indeed, even with the articles published in this special issue, there are far more unanswered questions - that demand additional research - than there are already answered questions to review. Gaining a comprehensive and comparative overview of the extent and variety of third-party funding in Europe is a research project that clearly needs more attention: We believe we have barely begun to reveal some of the most relevant questions concerning third-party funding of university-based business 
research, much less to develop theories to address these questions and empirically examine them.

Conceptually too, further research needs to develop greater traction over the major tensions underlying the implicit differences between the Anglo-Saxon and European models. These tensions, two of which are between dominantly epistemological (i.e. fundamental) vs. instrumental driven research, and between researcher/ university autonomy and public accountability, go to the core of what universities are actually for (see the related debate on rigor vs. relevance in management studies, e.g. Kieser et al. 2015).

There is little doubt that Austerity pressure on public purses across Europe is increasing the perceived need for research to be good value for money and that it has valuable direct impact that benefits society and the economy. Populist political and media pressures, as has been seen in recent European debates on the value for money represented by a university degree, Rector and Vice Chancellor salaries and the correspondence of research to business and societal problems, are likely to increase attention on the management and relevance of research and universities (Wiklund et al. 2018). The framing of public funding of research, both at national and EU levels, has in recent years progressively sought to encourage researchers to partner with industries and SMEs, and funding bodies have clearly become more attuned to framing scientific, social and economic problems in terms of existing ideological and institutional logics.

Indeed, there may be interesting opportunities to enhance research relevance and management through collaborating with corporate and other third-party funders (Adam et al. 2006; Gibbons 1994; Nowotny et al. 2001, 2013). For example, involving individual or organizational shareholders in the research process can help identify pertinent research questions, and probe the interpretations of findings, making them more actionable (van der Ven 2007). At the same time, relevance without rigor is not relevant (Wiklund et al. 2018). While several disciplines were originally rooted in real-life issues faced by the objects of study, early research was also oftentimes largely atheoretical and descriptive. Now that most fields have established legitimacy through epistemological driven research agendas and improvements in methodological rigor, there is risk that third-party funded research focusing on instrumental returns weakens fields' legitimacy. Individual academics and research fields as such may become more the servants of others' instrumental needs, and are less in pursuit of making epistemological progress (but see Adam et al. 2006 for a different perspective).

In addition, there is risk that the rise of third-party funding increases academia's fragmentation in terms of building a two-class society (i.e., university-funded publication-focused researchers versus third-party funded project-focused researchers). Such developments likely hold far-reaching implications for research management including metrics of performance such as criteria for tenure and promotion decisions (i.e., number of rigorous top publications versus amount of attracted thirdparty funding) and human resource practices (see e.g., Martin 2015). Inevitably, the boarders between academic sub-disciplines and their foci will change as a result of the shifts towards third-party funding detailed in this special issue. We believe multilevel studies of the role of third-party funding in academia measuring additional 
outcomes than solely research productivity would help to develop a deeper understanding of the trade-offs between rigor and relevance. Nevertheless, ongoing changes worldwide relating to complex societal needs suggest that, to remain actionable, some disciplinary areas may increasingly need to collaborate with corporate and other third-party funders and therefore integrate third-parties' utility considerations. In particular, rapid technological changes and changing socio-economic goals call for the application of resource-intensive research methods and tools that state bodies might not have the public mandate to fund, but still are required for rigorous research.

Underlying the tensions articulated in this special issue are perhaps concerns over researcher professionalism. The autonomy and rights of professions to manage and control their own work is, like many other spheres of work, coming under greater technological and market pressure. It is not surprising that academics are facing similar challenges. The shift of funding research away from universities and public bodies and towards corporate and other third-party funders pushes the decision making about who (what type of academic) and what (which types of interests and expertise) gets funded away from professional research expertise and towards non-academia-based interests. This raises important questions as to the sources of power and tactics academics and universities can devise to maintain their research autonomy or independence - while being able to successfully exploit the opportunities of third-party funding such as access to monetary resources, and non-monetary resources in the form of data, tools and critical sounding boards. For example, to reduce dependency and increase autonomy, researchers may want to employ a diversification approach to their industry partnerships (i.e., reliance on multiple thirdparty funding sources), or grow too big to fail through publications in top journals.

We believe continued research on the interplay between different sources of power and governance tactics will be important to the continuing development of the understanding of the role of third-party funding of research. Academic research has, no doubt, always reflected dominant societal interests and prevailing power structures (Merton 1973). The continuing rise of third-party funding, might, however, cause a structural shift that could have profound implications for what university-based business research, and for how business research is conducted. It is also a phenomenon that deserves greater research scrutiny, if, that is, the third-party funding can be found to fund such empirical research!

\section{Acknowledgements Open access funding provided by Johannes Kepler University Linz.}

Open Access This article is distributed under the terms of the Creative Commons Attribution 4.0 International License (http://creativecommons.org/licenses/by/4.0/), which permits unrestricted use, distribution, and reproduction in any medium, provided you give appropriate credit to the original author(s) and the source, provide a link to the Creative Commons license, and indicate if changes were made. 


\section{References}

Adam M, Carrier M, Wilholt T (2006) How to serve the customer and still be truthful: methodological characteristics of applied research. Sci Public Policy 33:435-444

Baumgart P (2006) Universitäten im konfessionellen Zeitalter: gesammelte Beiträge (No. 149). Aschendorff

EUA - European University Association (2015) EUA Public Funding Observatory. http://www.eua.be. Accessed 11 Jan 2016

Geuna A, Martin BR (2003) University research evaluation and funding: an international comparison. Minerva 41(4):277-304

Gibbons M (ed) (1994) The new production of knowledge. the dynamics of science and research in contemporary sciences. Sage, London

Kieser A, Nicolai A, Seidl D (2015) The practical relevance of management research: turning the debate on relevance into a rigorous scientific research program. Acad Manag Ann 9(1):143-233

Lenzen D (2015) University of the world: a case for a world university system. Springer, New York

Martin R (2015) Interview, fortune magazine: are American business schools headed for a GM-like catastrophe? http://fortune.com/2015/08/17/business-schools-future/. Accessed 14 May 2018

Merton RK (1973) The normative structure of science. In idem, The sociology of science. Theoretical and empirical investigations. University of Chicago Press, Chicago

Nowotny H, Scott P, Gibbons M (2001) Re-thinking science: knowledge and the public in an age of uncertainty. Polity, Cambridge

Nowotny H, Scott PB, Gibbons MT (2013) Re-thinking science: knowledge and the public in an age of uncertainty. Wiley, Hoboken

Scherer RF, Javalgi RRG, Bryant M, Tukel O (2005) Challenges of AACSB international accreditation for business schools in the United States and Europe. Thunderbird Int Bus Rev 47(6):651-669

Starkey K, Madan P (2001) Bridging the relevance gap: Aligning stakeholders in the future of management research. Brit J Manag 12(Special Issue):3-26

Van de Ven A (2007) Engaged scholarship: a guide for organizational and social research. OUP, Oxford

Wiklund J, Wright M, Zahra SA (2018) Conquering relevance: entrepreneurship research's grand challenge. Entrep Theory Pract. https://doi.org/10.1177/1042258718807478

Zwick E (2010) Von Pfründen zu Drittmitteln: Bildungsfinanzierung aus historischer Sicht am Beispiel der Universitäten. In Handbuch Bildungsfinanzierung. VS Verlag für Sozialwissenschaften, pp. $113-121$

Publisher's Note Springer Nature remains neutral with regard to jurisdictional claims in published maps and institutional affiliations.

\section{Affiliations}

\section{Matthias Fink ${ }^{1,2}$ D Isabella Hatak ${ }^{3,4} \cdot$ Markus Scholz $^{5} \cdot$ Simon Down ${ }^{2}$}

Isabella Hatak

isabella.hatak@unisg.ch

Markus Scholz

markus.scholz@fh-wien.ac.at

Simon Down

simon.down@anglia.ac.uk

1 Institute of Innovation Management, Johannes Kepler University Linz, Altenbergerstrasse 69, 4040 Linz, Austria

2 School of Management, Anglia Ruskin University, East Rd, Cambridge CB1 1PT, UK

3 KMU-HSG, University of St. Gallen, Dufourstrasse 40a, 9000 St. Gallen, Switzerland 
4 NIKOS, University of Twente, PO Box 217, 7500 AE Enschede, The Netherlands

5 Endowed Chair of Corporate Governance and Business Ethics, University of Applied Sciences for Management and Communication Vienna, Währinger Straße 61, 1090 Vienna, Austria 